\title{
Nasopharyngeal Keratinizing Squamous Cell Carcinoma
}

National Cancer Institute

\section{Source}

National Cancer Institute. Nasopharyngeal Keratinizing Squamous Cell Carcinoma. NCI Thesaurus. Code C7992.

A squamous cell carcinoma that arises from the nasopharynx and is characterized by prominent production of keratin. 